Meta

Journal des traducteurs

Translators' Journal

\title{
The Translatability of Interjections: A Case Study of Arabic-English Subtitling
}

\section{Mohammad Ahmad Thawabteh}

Volume 55, numéro 3, septembre 2010

URI : https://id.erudit.org/iderudit/045067ar

DOI : https://doi.org/10.7202/045067ar

Aller au sommaire du numéro

Éditeur(s)

Les Presses de l'Université de Montréal

ISSN

0026-0452 (imprimé)

1492-1421 (numérique)

Découvrir la revue

Citer cet article

Thawabteh, M. A. (2010). The Translatability of Interjections: A Case Study of Arabic-English Subtitling. Meta, 55(3), 499-515. https://doi.org/10.7202/045067ar
Résumé de l'article

Le présent article examine la traductibilité des interjections arabes dans un sous-titrage anglais. La recherche est illustrée par un film égyptien, intitulé State Security (La sécurité d'État), qui est sous-titré par le réseau de radio et de télévision arabe (Arab Radio and Television Network; ART). Le cadre théorique relatif à la traduction audiovisuelle (TAV) et aux interjections est tout d'abord présenté. L'importance des interjections est abordée du point de vue des paradigmes techniques et traductionnels. L'étude montre que, bien que les questions techniques limitent le choix des sous-titreurs, elles ont peu d'influence sur la traduction des interjections, car celles-ci sont généralement des mots courts. En ce qui concerne la traduction, l'étude montre que le sous-titreur peut opter pour trois grandes stratégies: 1) ne pas prendre en compte l'interjection dans la langue source (LS) et utiliser une expression sans interjection dans la langue cible (LC); 2) prendre en considération l'interjection dans la LS et la traduire dans la LC; 3) ajouter une interjection dans la LC alors qu'elle est absente dans la LS. 


\title{
The Translatability of Interjections: A Case Study of Arabic-English Subtitling
}

\author{
MOHAMMAD AHMAD THAWABTEH \\ Al-Quds University, Jerusalem, Occupied Palestinian Territories \\ mthawabteh@arts.alquds.edu
}

\begin{abstract}
RÉSUMÉ
Le présent article examine la traductibilité des interjections arabes dans un sous-titrage anglais. La recherche est illustrée par un film égyptien, intitulé State Security (La sécurité d'État), qui est sous-titré par le réseau de radio et de télévision arabe (Arab Radio and Television Network; ART). Le cadre théorique relatif à la traduction audiovisuelle (TAV) et aux interjections est tout d'abord présenté. L'importance des interjections est abordée du point de vue des paradigmes techniques et traductionnels. L'étude montre que, bien que les questions techniques limitent le choix des sous-titreurs, elles ont peu d'influence sur la traduction des interjections, car celles-ci sont généralement des mots courts. En ce qui concerne la traduction, l'étude montre que le sous-titreur peut opter pour trois grandes stratégies: 1) ne pas prendre en compte l'interjection dans la langue source (LS) et utiliser une expression sans interjection dans la langue cible (LC); 2 ) prendre en considération l'interjection dans la LS et la traduire dans la LC; 3 ) ajouter une interjection dans la LC alors qu'elle est absente dans la LS.
\end{abstract}

\begin{abstract}
This paper examines the translatability of Arabic interjections into English subtitling, illustrated with a subtitled Egyptian film, State Security subtitled by Arab Radio and Television (ART). Theoretical framework regarding both Audiovisual Translation (AVT) and interjections is first discussed. The significance of interjections is approached from the perspective of technical and translation paradigms. The study shows that although technical issues limit the subtitler's choices, they have very little to do with translating interjections because they are typically short words. With regard to translation, the study shows that the subtitler may opt for three major translation strategies: 1) an avoidance of source language $(\mathrm{SL})$ interjection whereby a SL interjectional utterance is translated into a target language (TL) interjection-free utterance; 2 ) a retention of SL interjection in which SL interjection is rendered into a TL interjection; and 3) an addition of interjection whereby $S L$ interjection-free utterance is translated into a TL interjection.
\end{abstract}

\section{MOTS-CLÉS/KEYWORDS}

interjections, stratégies, traduction audiovisuelle, sous-titrage

interjections, translation strategies, audiovisual translation, subtitling

\section{Introduction}

An approach to studying Audiovisual Translation (henceforth AVT) is typically eclectic in nature as it involves technology, semiotics, linguistics and other areas of knowledge. This interdisciplinary approach does not allow for a comprehensive review of AVT, but rather for a more specific area of study, that is, translating Arabic interjections into English as far as this paper is concerned. 
Very rapid and monumental technological development gave a new lease on life to AVT, and it is particularly important to recognise that research in this area should be concomitant with such development for better understanding of the extreme difficulties the translator is likely to face in this context. AVT includes various means of language transfer, the most predominant are dubbing and subtitling (Baker 1998). The former covers "the original voice in an audio-visual production by another voice" (Dries 1995: 9). The latter refers to a linguistic practice that aims to offer a written text, normally at the bottom of the screen (Díaz Cintas 2001: 23). Gottlieb (1992) describes subtitles as "transcriptions of film or TV dialogue, presented simultaneously on the screen [and] usually consist of one or two lines of an average maximum length of 35 characters" (Baker 1998: 245; see also De Linde and Kay 1999: 6). Suffice to say that AVT poses demands on the subtitler or dubber quite different from those of text translation. This is due to the technical aspect usually involved in AVT. In this regard, Kruger explains:

The difference between the skills required for subtitling and those required for translation, editing or interpreting, lies in the very technical aspects of subtitling. Subtitling requires all the skills that other modes require in terms of text analysis, subject expertise, language, awareness of context, quality control and so forth, but it also requires that the subtitler to be able to apply these skills within very rigid constraints of time and space, while adhering to specific conventions of quantity and form. Mastering and applying these skills take a long time (Kruger 2008: 82).

In dubbing, "translators are faced with more constraints than in written translation, notably constraints imposed by the image. Especially noteworthy are lip-sync and isochrony" (Díaz Cintas 2008: 14). By corollary, the subtitler or dubber needs to be sufficiently versatile to produce a high-quality AVT, not only linguistically, but also technically. The need for further research on coping with such changes, with all of the linguistic and technical problems they entail, has become rather urgent.

Beyond mere entertainment, subtitled films attract people due to their potential for narrowing the cultural gap in a linguistically diverse audience share, and the film cognoscenti are more or less assumed to be a culture-phile of other traditions. In terms of better intercultural exchange, one can assume that what politics cannot do, films can do. Whilst politics has been a source of disenchantment and despair for many countries, films encourage tolerance and understanding of an inherently diverse human nature. With a desire to watch more films and a propensity for cultural awareness, Arab viewers, like many others, can watch at least three satellite channels broadcasting Arab and foreign films around the clock, with subtitles either in Arabic (e.g., MBC2), or in English (e.g., Rotana Cinema, ART, Aflam, etc.).

\section{Interjections}

There are two different viewpoints as far as interjections are concerned. Wilkins (1992: 120) says that interjections are "semantically rich and have a definite conceptual structure" (see Ameka 1992; Wharton 2003), and are treated as part of language. By contrast, Goffman (1981: 100) claims that an interjection is "a ritualised act." It ensues then that interjections "are not part of language, and are analysed in terms of the socio-communicative roles they play, rather than any linguistic content they may have" (Wharton 2003: 40). Regardless of being (not) part of language, interjec- 
tions are notably means by which we communicate every subtle nuance of our emotions. As a point of departure, it is necessary to propose a conceptual framework regarding interjections both in English and Arabic.

\subsection{English}

Ameka (1992: 107) stresses the importance of interjections in intercultural communication, pointing out that they "form a significant subset of those seemingly irrational devices that constitute the essence of communication." Although interjections have received less attention than other language components or, in the words of Cuenca (2006: 20) "peripheral to language and similar to nonlinguistic items such as gestures and vocal paralinguistic devices," they play a crucial role in communication. Therefore, a better understanding of their function might be of the essence to the tasks we would normally expect of a subtitler. Nevertheless, linguistics pays little attention to the study of interjections as a minor word-class in comparison with other major word-classes. De Beaugrande (2008: 296) points out that interjections have always been a neglected area in linguistics, and have received "jolly little respect from most 'grammars,' even large ones” (see also Ameka 1992; Wharton 2003).

Methodologically, Carter and McCarthy speak of pragmatic markers as "a class of items which operate outside the structural limits of the clause and which encode speakers' intentions and interpersonal meanings." They include:

1) Discourse markers, which indicate the speaker's intentions with regard to organising, structuring and monitoring the discourse;

2) Stance markers, which indicate the speaker's stance or attitude vis-à-vis the message;

3) Hedges, which enable speakers to be less assertive in formulating their message; and

4) Interjections, which indicate affective responses and reactions to the discourse.

(Carter and McCarthy 2006: 105)

Following on from the above, Schiffrin (1987: 31) states that discourse markers are "sequentially dependent elements which bracket units of talk." Carter and $\mathrm{McCarthy}$ distinguish $\mathrm{Oh}$ as an interjection and as a discourse marker. As an interjection, $\mathrm{Oh}$

[e]xpresses surprise, disappointment and pain. As a discourse marker, [it] is used in particular to respond to new information or to indicate that a speaker has just discovered something surprising. The extent of the surprise can sometimes be indicated by a marked tone of voice which is represented in writing by ohoh and oooh (Carter and McCarthy 2006: 57).

Interjections can also be derived from nouns as Norrick (2007: 6; italics in original) has found: "We find interjections from nouns such as boy and shit, apparent verbs such as damn and fuck, and phrases like goddamn from goddammit, often in reduced forms such as blimey from God blind me." In addition, there are "free-standing interjections which are common as back-channels or attention signals, especially forms like wow, gee or jeez $z^{1}$ and whoa" (Norrick 2007: 6; italics in original).

De Beaugrande speaks of a hierarchy of interjections saying that they can be identified into three sub-classes: 
1) Sound interjections whose function is realised by the way they sound. For example, ugh signals disgust, but can also be used to overcome silence in printed media, as in cartoon;

2) Vowel interjections with one vowel sound; they can signal ameliorative or pejorative; and

3) Consonant interjections that can be drawn-out, most common of which are nasal $[\mathrm{m}]$ and $[\mathrm{n}]$ and liquids [l] and [r]. Consonant interjections can be single-piece units and compressed like zounds from God's wounds (De Beaugrande 2008: 299-300).

Smidt (2002: 197) takes the discussion a step forward, saying that an interjection can have various meanings, "from indifference to comprehension, incomprehension, query, rebuttal, rebuke, indignation, impatience, disappointment, surprise, admiration, disgust and delight in a number of degrees."

\subsection{Arabic}

Farghal and Borini (1998: 156) argue that "[o]ne of the main roots of the problem of translating interjections from Arabic into English seems to be the lack of theoretical linguistic research in Arabic regarding this area." Such a claim seems to be amorphous due to the voluminous literature on Arabic interjections. In fact, research on Arabic interjections is as old as scholarly endeavour itself (see Sibawayhi 1966; AlDahdah 1992 and Hmouz 2007, among many others). The esoterically inclined Arab grammarians would have left no stone unturned in their search for further explanations of the many linguistic phenomena involved in Arabic. The problem has nevertheless been obvious in the absence of clear-cut hierarchies for several linguistic phenomena including interjections. The translation of the Qur'an highlighted a semantic import of the interjection 'ufin: "Whether one or both of them attain old age in thy life, say not to them a word of contempt, nor repel them" (Ali 17: 23). ${ }^{2}$ The rebuffing interjection 'ufin, which translates "a word of contempt," is the epitome of the many interjections which permeate Arabic. The same interjection is translated into Ugh in Shakir's translation and Fie in Pickthall's translation. ${ }^{3}$

Broadly speaking Arabic interjections fall into two major categories: those which evolve from verbs are called 'asmā al-'f'āl (verbal nouns) and those which come from sounds are called 'asmā al-'a swāt (sound-effect nouns). Arabic interjections share some features with those of English, but nevertheless differ in many ways. Al-Dahdah (1992: 71) states that the functionality of 'asmā al-'f'āl is based on the meaning of the past verb, e.g., haihāt (How impossible!); the conform verb, e.g., zih, and 'awwah (Wow!, Ouch! respectively); the imperative, e.g., 'ihi (Hooray!); and what is improvised, e.g., 'ufin (Damn!).

Sound-effect nouns, however, are interjections used for the sounds of animals or human beings. For example, kix $(U g h)$ is a sound-effect interjection that can be used to admonish a small child not to put strange objects in his mouth.

Perhaps another view about interjection worth mentioning is that of Al-Tha'albi (1972: 216). He speaks of pair interjections or rhyming interjections. As can be shown in table 1 below, rhyming interjections may be universal. 
TABLE 1

Arabic Rhyming Interjections

\begin{tabular}{|l|l|l|}
\hline Arabic Interjection & Possible English Equivalent & Arabic Function \\
\hline qih qih & Ha ha! & Giggling \\
\hline sah sah & Hush! & Request for quietness \\
\hline da' da' $^{\text {' }}$ & Hip hip! & Happiness \\
\hline 'ax'ax & Ouch! & Pain expression \\
\hline zih zih & Wow! & Satisfaction \\
\hline nah nah & Hello! Anybody there? & Permission signal \\
\hline
\end{tabular}

That being the case, translating interjections from Arabic into English seems to be functionally and / or formally feasible. For example, qih qih and $\mathbf{d a}^{\mathbf{c}} \mathbf{d a} \mathbf{a}^{\mathbf{c}}$ can be translated into English ha ha! and hip hip! respectively.

\section{The Problem of Equivalence}

The concept of equivalence is deeply rooted in translation studies. Many translation theorists and practitioners argue that each language has its own peculiarities in terms of syntax, semantics, pragmatics, stylistics and culture and exact equivalence is rather difficult, if not impossible. In this regard, Tytler (1790: 20) points out that an "evaporation of the beauties of the original" is expected to occur in the course of translation.

With regard to Arabic and English, we argue that the lack of formal equivalence should be taken at face value. First, whilst Arabic is a right-to-left joined-up language, whereby the letters of a single word can work by ligatures, English is a left-to-right language. Secondly, the beginning of a book, a short story, etc. for a right-to-left language reader is the ending for a left-to-right language reader, as is the reverse (see Thawabteh 2006: 187).

With this in mind, non-equivalency in translation from English into Arabic, or vice versa, seems to be taken for granted. According to Pym:

Equivalence, no matter what its nature, does not simply exist between locales. Equivalences are created by internationalization or translation of one kind or another. They are necessary fictions without necessary correlative beyond the communication situation. In this sense, translation is not a mapping of one function onto another; it is a productive function in itself. Translational equivalence is thus ultimately determined by what translators actually do or have done in the past, and not by abstract comparisons between falsely discrete languages and cultures (Pym 2004: 62).

Nevertheless, since the problem of equivalence has been looming large in translation studies, there is a consensus of opinion among translation theorists and practitioners that regards equivalence as a matter of singular importance in translation (Nida 1964; Catford 1965; and Newmark 1988, among many others).

\section{Problems of Translating Arabic Interjections}

It is quite true that "[t]ranslation may be a cognate of the interjection in the source language," (Aijmer 2002: 107) and hence potential translation with minimal difficulties. For example, the English wow corresponds phonologically to Arabic wāw. However, cognate words can only be related at morpho-phonological level, but not 
at semantic or pragmatic level, as is the case with the Irish and Scottish Och. While it is used in English to "express surprise at something, or to emphasize agreement or disagreement with what has just been said" (Collins Cobuild 1995: 1140), in Arabic it is used with guttural sound, to shout at a baby not to tug at his mother's hair, for instance. The English attention getting sound ahem may be a cognate of Arabic 'him which serves more or less the same meaning (see Farghal and Borini 1998: 157). Therefore, the essence of the problem of translating interjections may be described in terms of pragmatic imports they would bear, which is likely to befuddle the novice translator. In this regard, Farghal and Borini (1998: 156) speak of failure on the part of the translators to abide by the pragmatic criteria of the interjection ya sātir (or alternatively ya sitīr), which can be placed under an-nidā (vocative) inasmuch as Arabic theoretical linguistics demonstrates. Added to that, we argue, is the problem of culture-specificity, that is, being mahram (a degree of consanguinity preventing marriage - Wehr 1974) or ghayr mahram (marriageable individuals) "permeates stratum of Muslim and Arab societies, and most of socio-cultural practices of Arabs and Muslims are governed by relationship to women" (Thawabteh 2008: 8). In Islamic context, using permission-taking formulae turns out to be obligatory as the Qur'an states "O ye who believe! enter not houses other than your own, until ye have asked permission and saluted those in them: that is best for you, in order that ye may heed (what is seemly)" (Ali 24: 27). ${ }^{4}$

Likewise, we previously touched on the translation of the Arabic imperative interjection wahiddūūūūh (for God's sake, be tolerant!), pointing out that the marked tone of voice evokes an interpretation alien to an English speaker (Thawabteh 2006: 74). The translator's strategy was based on reiterating [u] as Wahidduuuuh, ${ }^{5}$ a strategy which may express surprise in English (Carter and McCarthy 2006). Yet the diminishing or even vanishing status of the interjection is clear-cut, probably due to the strategy employed. In Arabic, the reiteration of [ū] is intended to highlight a sociocultural practice by a Sufi adept uttering the interjection to procure a wide range of physical and spiritual boons. In this respect, we explained:

The marked tone of voice [...], which is represented in writing by repeating the letter $[\bar{u}]$, is an indication of Islamic mysticism in which mystics go through a kind of nascent spiritual practices, uttering this interjection with a drawn-out voice by reiterating the Arabic letter $[\bar{u}]$ (Thawabteh 2006: 74).

As can be noted, the SL interjection indicates that a mystic is at pains to acquire equanimity. The functionality of interjections in Arabic and the way they are dealt with in translation may pose a problem very much related to pragmalinguistic issues and culture-specificity.

In terms of subtitling interjections, the switch from spoken to written language mode and all that aggro constitutes a hindrance to the wheels of intercultural communication. Perego points out:

The transfer from spoken to written language [...] entails the loss of many prosodic features inherent in the spoken code, such as tone and modulation of the voice, regional accents or sociolinguistic markers (i.e., grammatical peculiarities), which are important sociolinguistic indicators (Perego 2003: 65).

It ensues then that subtitlers may have a Sword of Damocles hanging over their heads in terms of the technicalities of subtitling and special language conventions. The sub- 
titler may successfully translate an utterance, but s/he has to modify or even alter the translation so that it can mesh with the many technical constraints of subtitling.

\section{Translation Strategies}

It is an oft-repeated truism that rendering a stretch of utterance successfully can help narrow the linguistic and cultural gulf between different languages and cultures. This implies that the translator should be, or even must be, fastidious in dealing with translation problems $v i s-\grave{a}-v i s$ translating language pairs in general and interjections in particular. One might understand a given translation, but still not internalise it, and hence devising an appropriate strategy turns out to be necessary. Scott-Tennent, Davies, et al. (2000: 108) define translation strategies as "the steps, selected from a consciously known range of potential procedures, taken to solve a translation problem which has been consciously detected and resulting in a consciously applied solution." Categorically, ostensible translation can observe either formal equivalencebased strategies or functional equivalence-based strategies. Included under the former are literal translation and transliteration (see Catford 1965: 66; Nida and Taber 1969). It is worth mentioning that in the case of languages with little affinity, such as Arabic and English, such strategies can result in grotesque translations. The latter, however, includes transposition, translation by paraphrase, modulation, among many others. It may be proper to argue that functional equivalence-based strategies are feasible solutions for facilitating communication between two language pairs, particularly when it comes to translating interjections. It is necessary to consider the pragmatic meaning of an interjection rather than its literal meaning.

Insofar as subtitling interjections is concerned, Chen describes the strategies to be employed in the course of translation:

Using the same interjections repeatedly in the subtitle should be avoided. Second, Chinese counterparts, or similar Chinese interjections, should be used if they are available; otherwise, Chinese interjections should be created based on Chinese word formation principles. Third, swearwords should be toned down if the movie is for minors or a general audience; however, they should be translated faithfully for an adult audience to show the tone of the movie (Chen 1996, cited in Chen 2004: 119).

Furthermore, Cuenca (2006) differentiates six strategies for translating interjections with particular reference to dubbing:

- Literal translation (strategy a);

- Translation by using an interjection with dissimilar form but the same meaning (strategy $b$ );

- Translation by using a non-interjective structure with similar meaning (strategy c);

- Translation by using an interjection with a different meaning (strategy $d$ );

- Omission (strategy e);

- Addition of elements (strategy f) (Cuenca 2006: 27; italics in original).

It follows that use of interjections in a communication exchange greatly assists the flow of communication, to the point that in the case of non-existence between language pairs, interjection creation becomes highly recommended in a translation activity. It should be borne in mind, however, that rarely do translators have leeway to add interjections. In fact, Arabic uses the neologism wāw (from English wow). 
However, we may argue against what Chen has proposed - frequent use of interjection should be avoided. In our view, the frequent use of an interjection is governed by the extent to be expressed in a written mode, on the one hand, and availability of the spatial dimension on the other.

\section{Methodology}

\subsection{Significance of the Study}

AVT is an embryonic academic discipline in the Arab World and only recently has it begun to gain momentum and weight - Arab studies on AVT seem to be on the increase (see Athamneh and Zitawi 1999; Khuddro 2000; Zitawi 2003 and 2008; Bahaa-Eddin 2006; Gamal 2008 and 2009). For instance, AVT is almost absent from the curriculum of Palestinian universities offering translation programmes except for Al-Quds University ${ }^{6}$ and from the practices of local Palestinian channels (see Thawabteh 2009). This may signify a lack. With advances in technology (e.g., internet, videogames, DVDs, teletext, etc.), subtitling possibilities are increasing.

By the same token, studies of Arabic interjections in relation to translation are rare as is the case in other languages, perhaps with the exception of the study we refer to in this paper (Farghal and Borini 1998). A call was made to study interjections in different languages (Ameka 1992: 116). The present paper is intended to shed new light on AVT and interjections in the Arab world, and in so doing delineate a path for further research in Arabic and other languages.

Hopefully, this paper will increase the Arab subtitlers' awareness of AVT as a form of translation which attracts widespread interest in many countries, and offer an insight into translating interjections. It is also hoped that the paper will assist subtitlers to overcome problems which may arise from translating interjections.

\subsection{Data Used in the Study}

The present paper comprises a screen translation taken from the English subtitled version of the Egyptian film 'Amn Dawlah subtitled by ART (1998) as State Security. The rational behind choosing the film lies in the various interjective structures it contains, which can be used for the sake of the study. Like many movies, State Security has been broadcast on different Arab satellite channels and states-run televisions. A transcription of the contextualised Arabic-loaded interjections is first made, taking into account the Egyptian dialect of the film. For the purpose of the study, a sample of 10 interjections, identified by the researcher as posing difficulties when translated into English, was chosen.

In the film, moments of poignancy are heartfelt when Samiha, convicted of murdering her father-in-law after he raped her, was sentenced to death. Nevertheless, she was given a heaven-sent opportunity, that her death sentence would be commuted into a release on condition that she agrees to work as an agent for Egyptian intelligence; she was deeply relieved and would not allow such an opportunity to slip through her fingers. As an agent recruited by Egyptian intelligence, she worked against miscreants and the lunatic fringe. She confirmed her knack for bringing a hardened criminal to justice and for capturing international terrorists. 


\section{Analysis of the Data and Discussion}

The theoretical framework established thus far requires that we examine particular examples in order to further corroborate and diversify our argument. It has been found that three major strategies are employed in the course of subtitling:

1) Avoidance of SL interjection;

2) Retention of SL interjection; and

3) Addition of interjection.

With reference to the strategies utilised for translating interjections proposed by Cuenca (2006), we can notice that strategy a) and b) are not employed as far as the current study is concerned whereas the other strategies are noticeable in our data.

\subsection{Avoidance of SL Interjection}

The subtitler may avoid translating the SL interjection into a corresponding TL interjection. Instead, s/he is likely to use ellipses as illustrated in Example 1 below:

(1) -āxir haqa fakrāha 'ayh? What's the last thing you remember?

-is-sijin $\underline{a} h$ al'i'dām $\underline{a} h$

Jail ... execution ...

(’Amn Dawla [State Security] 1999)

In the sequence of verbal sparring, the officer came to Samiha's rescue. Her extremely pessimistic view of life made her reluctant and unwilling to accept the officer's offer. A close look at Example 1 shows that the underlined interjections indicate short intakes of breath, that is, a filled pause marked by a vocalisation so that the speaker could select a structural basis for marking topic shift, i.e., 'i'dām as to the first interjection. The second interjection, however, is used to bring back excruciatingly painful memories, i.e., execution as far as the speaker is concerned.

The translator makes his/her overriding priority to avoid translating the Arabic interjections and instead, opts for ellipses, i.e., using unfilled pauses to indicate a silence. Carter and McCarthy (2006: 89) point out that "[u]nfilled pauses tend to occur when a shift in topic or a change in direction is about to occur. [...] Pauses of longer than one second are indicated by dots [...]." The translation of the SL interjection into dots seems to have done the trick insofar as the first interjection is concerned whereas the second interjection seems to be a dead loss.

As can be noted in Example 1, the SL interjections are avoided and replaced by functionally corresponding ellipses. Nevertheless, there is no harm in retaining interjections in the subtitled version, since brevity and spacing of the SL text still allows for such retention.

It may be worth reiterating that Arabic interjection occurred twice over in Example 2 and is meant to express the fears gnawing away at the back of the speaker's mind. Her mind flashed back to the moment when she was pinioned and hooded, a traumatic experience indeed.

(2) 'ašmāwi kan yuћut al-m'šna'a The executor was fixing the gallows 
hawl ra'bati ayh ayh around my neck.

('Amn Dawla [State Security] 1999)

Although some of the effect of the lexicogrammatical features in the subtitles, to some extent, reflects such an experience, the underlined Arabic interjections explicitly reveal devilish thoughts apropos the execution, gallows, etc. She was obsessed with gloomy prognostication about her future. Therefore, the SL interjectional formula is not recalcitrant in the sequence, but rather lays further emphasis. The translator could have opted for a corresponding English interjection, as technical considerations would still have allowed for the inclusion of an interjection.

With his owlish face, the officer's hidden agenda is clear in Example 3. As an intelligence officer whose job is to bring criminals to justice, he wished, by hook or by crook, to instil a sense of guilt in Samiha. Had the officer avoided the drawn-out vocalisation, his argument would have been weak and unconvincing. The officer reminds Samiha that she should hang on for dear life. Consider the following:

(3) 'intīi $\overline{1}$

You...

tam 'i'dāmik imbārih 'i s-subh

You were hanged yesterday morning,

w-indafanti fi ma'ābir a s-s sadaqa

and buried in the charity cemetery.

('Amn Dawla [State Security] 1999)

The marked tone of voice represented in the reiteration of Arabic single-letter [i] can be regarded as a filled pause intended to organise the discourse the best way possible and to express a potential face-threatening. With this in mind, the English subtitle seems questionable although the vocative You may serve the purpose. Yet the original Arabic expresses neither a shift in topic nor a change in direction whereas the subtitled English version does. In addition, the underlined segments can be seen as an interjection used to express sorrow - Samiha was supposed to be hanged the preceding day.

(4) āy w-'inta min ba'a?

Who are you, then?

'uzr'ìl?

Death angel?!

('Amn Dawla [State Security] 1999)

The underlined Arabic interjection ày in example 4 is phonetically and even pragmatically in harmony with the English eh, which according to Collins Cobuild (1995: 531) is used in writing "to represent a noise that people make as a response in conversation, for example to express agreement or to ask for something to be explained or repeated." Sometimes the interjection is combined with interrogatives to place greater emphasis on an immediate reply. The English interjection-free subtitle seems to be equivalent to the original utterance in Example 4. However, translating it into eh would reflect more interpersonal pragmatics with which the SL text is loaded. To further appreciate the problem of translating interjections, consider Example 5: 
(5) $\underline{\text { ahhhhh }}$

('Amn Dawla [State Security] 1999)

The TL audience is left to form an interpretation from visual cues. The message may be encoded without the need for subtitling because of paralinguistic features: the sound is indicated visibly on screen, thus "need not be transcribed" (De Linde and Kay 1999: 14). However, culture-specificity of pair languages should, or maybe must, be taken into account. The Arabic interjectional sound āhhhhh, which is a morphophonological cognate to English ah, signifies pain in this particular context and, it can be misleading for an English viewer. In a sense, the English interjection is used to "draw attention to something or to express surprise or disappointment" (Collins Cobuild 1995: 37).

This argument follows from what Ameka (1992: 106) has established: "Interjections are relatively conventionalised vocal gestures (or more generally, linguistic gestures) which express a speaker's mental state, action or attitude or reaction to a situation."

\subsection{Retention of Interjection}

What appears more important in communication is the production of adequate communicative units. Interjectional devices are a case in point. It is arguably true that translating a SL interjection into a TL interjection would best facilitate intercultural communication. We argue that technical constraints, e.g., spatial dimension nevertheless allow for use of interjections because of their brevity. By way of illustration, consider Example 6 below:

(6) yāh danta 'arif 'anni kuli haqah ahu Wow! You know everything all right!

(’Amn Dawla [State Security] 1999)

Obviously, yāh is an interjection which can signify surprise in the context of a situation. The speaker was surprised that the intelligence officer knew about the personal details of her chequered past. At fourteen, she killed her step-father who had brutally raped her. She was tried seven times for violent acts in prison, was sentenced to some 65 years, and finally, was sentenced to death for killing a cellmate and causing disabilities to two others. Similarly, but more precisely, the corresponding English Wow! is used when someone is very impressed, surprised, or pleased (Collins Cobuild 1995: 1939). The subtitling sounds optimal since the communicative thrust of the original Arabic is preserved in the English subtitled version. The strategy employed is interjection reciprocity between the SL and TL. For more elaboration, consider Example 7 below:

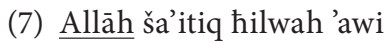

Wow! Your flat is great

sughayyrah bas fỉha zü' yīqannin

small but really stylish!

('Amn Dawla [State Security] 1999)

The Arabic interjection Allāh (literally the name of God in Islam) is obviously derived from a noun (see Norrick 2007). It has drifted from its semantic import by 
acquiring new illocutions, namely to introduce a remark or response expressing surprise, and hence becomes pragmatically multipurpose expression (for the translatability of a similar item: 'inšāllah, see Farghal 1995). As can be noted, the strategy employed for Wow, rather than, say, Jeez, seems to be successful as the latter expresses shock and even causes offence in English.

The intended Arabic interjections in Example 8 below merit close investigation. Samiha bawled āhhhh and āyyyy with such a drawn-out voice to express anger and pain. What is going on here is that an interjection of anger coincides with an interjection of pain although introducing one is sufficient to accommodate the other as is the case in the English subtitle whereby $O h$ ! is typically utilised to express emotions such as surprise, pain, annoyance, or happiness (Collins Cobuild 1995: 1147).

(8) Өāni dars: kul ghaltah wi-līha Өaman

Second lesson: you err, you pay!

wi-'inti lāzim tidfa īh

You have to pay now!

[shooting her in the leg]

āhhhh āyyyy ya-'bn-il-kalb

Oh, creep!

il-ghaltah al-qaiyah fi idmaghik

'itfū

('Amn Dawla [State Security] 1999)

The swearing phrase 'bn-il-kalb is more or less pragmatically similar to that of English - Creep. In a sense, the Arabic taboo 'bn-il-kalb with vocative ya is commonly used to insult another person as is 'Oh! Creep!.' Carter and McCarthy (2006: 105) point out that " $[\mathrm{s}]$ wearing often takes the form of interjections. This can involve single words or short phrases or clauses that are used to express a variety of strong feelings, in particular, annoyance, frustration and anger."

It should be noted that the interjection signifying hatred and / or contempt (i.e., 'itfū - to spit) is left untranslated. In original Arabic, Samiha spat at the misogynist officer after he shot her in the leg. Nevertheless, a flow of communication is preserved in the alternative blank subtitle by virtue of the semiotic webs displayed in the film sequence.

\subsection{Addition of Interjection}

It goes without saying that the purpose of translation is to facilitate intercultural communication between languages and cultures. As noted earlier, interjections are used to ease communication. Therefore, using interjections to translate interjectionfree utterances will come to no harm. Occasionally, the original Arabic happens to be interjection-free. The subtitler would opt for an interjection in the TL to facilitate communication as is the case in Example 9:

(9) -'inti muttī: Samīha 'Abdul-Mu'tī Šahīn ma ba’a-l-hāš wuqūd

- So, you're dead! Samiha Shahin no longer exists 
- mut?

- Oh yeah?!

(’Amn Dawla [State Security] 1999)

In this example, the SL interjection-free utterance is rendered into TL interjection Oh yeah?! In the dialogue, the officer metaphorically says that Samiha, the malefactor, is dead, and now he is speaking about another person who will work for Egyptian intelligence. Samiha could not read the officer's mind, thus she uses the tag question mut. In the subtitle, the translator opts for a TL interjection, which has the pragmatic import of the SL utterance. The translator's choice can also be considered as a discourse marker, for Oh yeah! is used in response to new information. To elaborate further, we should examine the next example:

(10) ya salām bi-l-basāta di? Oh yeah?! That simple?!

('Amn Dawla [State Security] 1999)

It is probably necessary to point out that in this film sequence, the chief and officer had spoken about recruiting Samiha. The officer, who already had a lot of contact with Samiha, now understands her personality, and is convinced she would be a strong asset to Egyptian intelligence, to raise the chief's eyebrows, as shown in Example 10. The Arabic vocative ya plus salām is an interjection commonly used to express amusement and surprise depending on the intonation. Rising intonation (e.g., ya salāām) expresses amusement whereas falling intonation expresses surprise as is the case in example 10 above. The subtitle seems to express the original.

\section{Concluding Remarks}

Thus far in our analysis, it has been noted that interjections are crucial in translation as a means of communication, and without them, there is a failure in communication or loss in interpersonal pragmatics. Interjections received little attention compared to other parts of language. In terms of the strategies employed in translating interjections, this discussion has shown that functional-based strategies can be an outlet because interjections are minimal communication elements in a language whose meaning dwells more on what's implied than what is actually said - pragmatic import. The study also shows that three strategies were employed, giving rise to convergence and divergence with Cuenca's (2006) differentiation of strategies for translating interjections. The three strategies are: avoiding translating SL interjection; retaining SL interjection in the TL and adding interjection into a TL. Strategy-wise, interjection reciprocity - translating a SL interjection into a TL interjection - reproduces the communicative thrust of SL utterance.

Technically speaking, the translation of a SL interjection into a TL counterpart poses no technical difficulties because they are usually short and fall within the allowable spatial dimension subtitling demands, as is the case with Example 4 and 2 where the number of characters is 18 and 15 respectively. The preference for brevity throughout most of the subtitling is important for the subtitler(s) in a general sense, and this brevity aligns with translating interjection.

Finally, Arabic and English interjections are cognate on occasion, a fact that lightens the task of the translator. That is, the problem of translating interjection 
would be minimal. However, as languages and cultures define reality in different ways, some interjections are culture-specific and thus pose a challenge for the translator.

\section{ACKNOWLEDGMENTS}

I owe a big debt of gratitude to Dr. Ibrahim El-Khawaja, Professor of Arabic Language and Literature at Al-Quds University, for his illuminating remarks on interjections; I am also sincerely indebted to Dr. Gina Dominique, Professor of American Literature at Al-Quds University, for her indefatigable spirit to help in handling the work of revising this paper. Thanks also go out to Dr. Imad El-Zeer at Al-Quds University. As always, responsibility for any shortcomings in the final version remains mine alone.

\section{NOTES}

1 Jeez (also Jees) is short for 'Jesus,' usually used when people are shocked or surprised about something. Also, 'Geez' is used to mean the same as 'Jeez,' with even more shades of meanings. See here $<$ http://www.urbandictionary.com/define.php?term=geez $>$, visited on 6 July 2010.

2. The Muslim Web-Qu'ran Browser, <http://www.themuslimweb.com/quran/browse.cgi?sura= $17 \&$ aya $=23 \&$ ya $=1>$, visited on 6 July 2010 .

3. The Muslim Web-Qu'ran Browser, $<$ http://www.themuslimweb.com/quran/browse.cgi?sura=17\&aya $=23 \& y a=1>$, visited on 6 July 2010 .

4. The Muslim Web-Qu'ran Browser, $<$ http://www.themuslimweb.com/quran/browse.cgi?sura=24\&aya $=27 \& y a=1>$, visited on 6 July 2010 .

5. The SL text reads "śraxa bi-sawtin mumtūt wahidduuuuh" (Bahgat 1986: 76-77) was translated by Nermeen Hassan (1988) as "He, then, shouted in a long drawn-out voice: 'Wahidduuuuh!'”

6. At undergraduate level, translation is offered as a minor at Birzeit University, Bethlehem University, and Arab American University of Jenin. At postgraduate level, higher diploma in translation is offered at Birzeit University and a master's degree in translation is offered at An-Najah University and Al-Quds University. The master's degree offered at Al-Quds University totals 39 credits, 15 of which are purely information technology-based, e.g., translation technology and term management, audiovisual translation etc.

7. 'Amn Dawla [State Security] (1999): Directed by Nader GaLal. Cairo: Šarikat Aswāt Mišr lil'Astūduhāt [Egypt Studios Company].

8. In this paper, Arabic transcription is first presented, followed by English subtitle(s). It should be noted that the reason for using two-line subtitle is based on what actually appears on the screen.

\section{REFERENCES}

Aijmer, Karin (2002): Interjections in a Contrastive Perspective. In: Edda Weigand, ed. Emotion in Dialogic Interaction. Amsterdam: John Benjamins, 99-120.

AL-DAhDAh, Antoine (1992): A Dictionary of Universal Arabic Grammar: English-Arabic. Beirut: Librairie du Liban.

Al-Tha'Albi, Abu Mansour (1972): Fiqih al-Lughah wa Sir al-'Aarabyiah. Edited and explained by Mustafa Al-SAQA, Ibrahim AL-Abyari and Abd il-Hafeez SHAlabi, eds. Cairo: Mustafa il-Babi il-Halabi.

Aмека, Felix (1992): Interjections: The Universal yet Neglected Part of Speech. Journal of Pragmatics. 18:101-118.

Athamneh, Nasser and Zitawi, Jihan (1999): English-Arabic Translation of Dubbed Children's Animated Pictures. Babel. 45(4):107-126.

BahaA-EdDin, Mazid (2006): Arabic Subtitles on English Movies: Some Linguistic, Ideological and Pedagogic Issues. IJAES. 7:81-100.

BAHgat, Ahmad (1986/1988): Ramadan Dairy. (Translated by Nermeen Hassan). Cairo: General Egyptian Book Organization.

BAKer, Mona, ed. (1998): Routledge Encyclopedia of Translation Studies. London: Routledge. 
De Beaugrande, Robert (2008): A Friendly Grammar of English. Visited 20 October 2008, $<$ www.beaugrande.com>.

Carter, Ronald and McCarthy, Michael (2006): Cambridge Grammar of English. Cambridge: Cambridge University Press.

Catrord, John C. (1965): A Linguistic Theory of Translation: An Essay in Applied Linguistic. London: OUP.

Chen, Sheng-Jie (2004): Linguistic Dimensions of Subtitling. Perspectives from Taiwan. Meta. 49(1):115-124.

Collins Cobuild English Dictionary (1995). The University of Birmingham: HarperCollins Publishers.

Cuenca, Maria (2006): Interjections and Pragmatics Errors in Dubbing. Meta. 51(1):20-35.

Díaz Cintas, Jorge (2001): Teaching Subtitling at University. In: Sonia Cunico, ed. Conference Proceedings. (Training Translators and Interpreters in the New Millennium, Portsmouth, 17 March 2001) Portsmouth: University of Portsmouth, 29-44.

Díaz Cintas, Jorge (2008): Introduction: The Didactics of Audiovisual Translation. In: Jorge Díaz Cintas, ed. The Didactics of Audiovisual Translation. Amsterdam: John Benjamins, $1-18$.

Dries, Josephine (1995): Dubbing and Subtitling: Guidelines for Production and Distribution. Manchester: The European Institute for the Media.

Farghal, Mohammed (1995): The pragmatics of 'inšallah in Jordanian Arabic. Multilingua. 14(3):253-270.

Farghal, Mohammed and Borini, Ahmad (1998): Pragmalinguistic Failure and the Translatability of Arabic Politeness Formulas: A case study of Mahfouz's Awlad Haritna. In: Abdullah Shunnaq, Cay Dollerup and Mohammed Saraireh, eds. Issues in Translation. Jordan: Irbid National University, 143-168.

Gamal, Muhammad (2008): Egypt's Audiovisual Translation Scene. Arab Media and Society. 5: 1-15. Visited 20 March 2010, <http://www.arabmediasociety.com/?article=675>.

Gamal, Muhammad (2009): Adding Text to Image: Challenges of Subtitling Non-Verbal Communication. Journal of Multicultural Research. 1. Visited 20 March 2010, <http://www. academicpress.us/Journals/ebooks/J2/3.pdf $>$.

Goffman, Erving (1981): Forms of Talk. Oxford: Blackwell.

Gottlieb, Henrik (1992): Subtitling - a New University Discipline. In: Cay Dollerup and Anne LODDERGaARD, eds. Teaching Translation and Interpreting Training, Talent and Experience. Amsterdam: John Benjamins, 61-70.

Hмouz, Mohammad (2007): Mu' jam 'Asmā al-'Aswat wa hikyatiha. Amman: Dār Safā lil-Tiba'ati wa Našri wa Tawzī‘.

Khuddro, Ahmad (2000): Subtitling in Arabic. Turjuman. 9(1):31-37.

Kruger, Jan-Louis (2008): Subtitling Training as Part of A General Training Programme in the Language Professions. In: Jorge DíAz Cintas, ed. The Didactics of Audiovisual Translation. Amsterdam: John Benjamins, 71-87.

De Linde, Zoe and Kay, Neil (1999): The Semiotics of Subtitling. Manchester: St. Jerome.

Newmark, Peter (1988): A Text Book of Translation. New York: Prentice Hall.

NidA, Eugene (1964): Towards the Science of Translation. Leiden: E.J. Brill.

Nida, Eugene and Taber, Charles (1969): The Theory and Practice of Translation. Leiden: E.J. Brill.

Norrick, Neal (2007): Pragmatic markers, interjections and discourse. Catalan Journal of Linguistics. 6:159-168.

Perego, Elisa (2003): Evidence of Explicitation in Subtitling: Towards A Categorisation. Across Languages and Cultures. 4(1):63-88.

Pym, Anthony (2004): The Moving Text: Localisation, Translation and Distribution. Amsterdam: John Benjamins.

Schiffrin, Deborah (1987): Discourse Markers. Cambridge: Cambridge University Press. 
Scott-Tennent, Christopher, Davies, Maria and Torras, Fernanda (2000): Translation Strategies and Translation Solutions: Design of a Teaching Prototype and Empirical Study of its Results. In: Allison Beeby, Doris Ensinger and Marisa Presas, eds. Investigating Translation. Amsterdam: Benjamins, 107-116.

Sibawayhi, Abu Bišr 'Amr (1966): 'Al-Kittab. Edited and explained by Abdel Salām Harūn. Cairo: Dārul-Qalam.

Smidt, Kristian (2002): Ideolectic Characterisation in A Doll's House. Scandinavica. 41(2):191206.

Thawabten, Mohammad (2006): Translating Arabic Cultural Signs into English: A discourse Perspective. Doctoral dissertation unpublished. Granada: University of Granada.

Thawabteh, Mohammad (2008): The Function of Cultural Reference within the Hermeneutic Circle: The Case of Arabic-English Translation. Applied Semiotics/Semiotique Appliquée. 21(8):5-15.

Thawabten, Mohammad (2009): Apropos Translator Training Aggro: A case study of the Centre for Continuing Education. The Journal of Specialised Translation. 12:166-179.

Tytlen, Alexander (1790): Essay on the Principle of Translation. London: J.M. Dent Co.

Wehr, Hans (1974): Arabic-English Dictionary. J Milton Cowan, ed. Beirut: Librairie du Liban.

Wharton, Tim (2003): Interjections, Language, and the 'Showing/Saying' Continuum. Pragmatics and Cognition. 11(1):39-91.

WiLKINs, David (1992): Interjections as Deictics. Journal of Pragmatics. 18:119-158.

Zitawi, Jehan (2003): English-Arabic Dubbed Children's Cartoons: Strategies of Translating Idioms. Across Languages and Cultures. 4(2):237-251.

ZitaWI, Jihan (2008): Contextualizing Disney Comics within the Arab Culture. Meta. 53(1):139153. 


\section{APPENDIX}

Transliteration System

A. Consonant

\begin{tabular}{|c|c|c|c|c|c|}
\hline b & $=$ & ب ب & $\underline{\mathrm{t}}$ & $=$ & b \\
\hline $\mathrm{t}$ & $=$ & ت & $\underline{\mathrm{z}}$ & $=$ & ظ \\
\hline$\theta$ & $=$ & ث & ' & $=$ & $\varepsilon$ \\
\hline J & $=$ & ج & $\mathrm{gh}$ & $=$ & $\dot{\varepsilon}$ \\
\hline$\hbar$ & $=$ & $\tau$ & $\mathrm{f}$ & $=$ & ف \\
\hline $\mathrm{x}$ & $=$ & $\dot{\tau}$ & $\mathrm{q}$ & $=$ & ق \\
\hline $\mathrm{d}$ & $=$ & د & $\mathrm{k}$ & $=$ & ك5 \\
\hline ð & $=$ & ذ & 1 & $=$ & J \\
\hline$r$ & $=$ & נ & $\mathrm{m}$ & $=$ & م \\
\hline $\mathrm{Z}$ & $=$ & j & $\mathrm{n}$ & $=$ & ن \\
\hline $\mathrm{S}$ & $=$ & س & $\mathrm{h}$ & $=$ & 0 \\
\hline$\check{\mathrm{s}}$ & $=$ & ش & $\mathrm{w}$ & $=$ & 9 \\
\hline$\underline{\mathbf{S}}$ & $=$ & ص & $\mathrm{y}$ & $=$ & ي \\
\hline$\underline{\mathrm{d}}$ & $=$ & ض & ' & $=$ & 4 \\
\hline
\end{tabular}

B. Elongated sounds

$\begin{array}{lll}\overline{\mathbf{a}} & \text { elongated } & \mathrm{a} \\ \overline{\mathbf{i}} & \text { elongated } & \mathrm{i} \\ \overline{\mathbf{u}} & \text { elongated } & \mathrm{u}\end{array}$

The IPA transliteration system is used, with the following modifications:

$\begin{array}{rrl}\underline{\mathbf{s}} & \text { to represent } & \text { ص } \\ \underline{\mathbf{d}} & \text { to represent } & \text { ض } \\ \underline{\mathbf{t}} & \text { to represent } & \mathbf{b} \\ \underline{\mathbf{z}} & \text { to represent } & \text { b } \\ \mathbf{j} & \text { to represent } & \mathbf{T} \\ \mathbf{g h} & \text { to represent } & \dot{\varepsilon}\end{array}$

